\title{
AIRPOLISHING EFFECT ON BOVINE ENAMEL AND THE POSTERIOR REMINERALIZING EFFECT OF SALIVA. AN IN VITRO STUDY
}

\author{
EFEITO DO JATO DE BICARBONATO DE SÓDIO SOBRE O ESMALTE BOVINO E \\ POSTERIOR EFEITO REMINERALIZADOR DA SALIVA. ESTUDO IN VITRO
}

Helena Zaramella Vono RIBEIRO ${ }^{1}$, José Eduardo de Oliveira LIMA², Bernardo Gonzalez VONO ${ }^{3}$, Maria Aparcida de Andrade Moreira MACHADO², Salete Moura Bonifácio da SILVA²

1- MSc, Graduate Studant, Department of Pediatric Dentistry, Bauru School of Dentistry, University of Sao Paulo.

2- PhD, Assistant Professor, Department of Pediatric Dentistry, Bauru School of Dentistry, University of Sao Paulo.

3- PhD, Titular Professor, Department of Pediatric Dentistry, Bauru School of Dentistry, University of Sao Paulo.

Corresponding address: Helena Zaramella Vono Ribeiro - Praça Salim Haddad Neto, 13-10 Ap. 1402, Vila Universitária

Cep.: 17012-503 - Tel.: (14)32270642 - helenavono@hotmail.com

Received: May 8, 2005 - Modification: January 30, 2006 - Accepted: March 24, 2006

\begin{abstract}
$P$

urpose: The aim of the present study was to evaluate the alterations of surface microhardness and wear caused by the sodium bicarbonate jet on bovine enamel and the further remineralizing effect of artificial saliva. Methods: Fifteen enamel samples $(4,0 \mathrm{~mm} \times 4,0 \mathrm{~mm})$ were used, which constituted the groups: no treatment (MI); treatment with sodium bicarbonate jet (MII and DI); treatment with sodium bicarbonate jet and immersion in saliva for one hour (MIII and DII), 24 hours (MIV and DIII) and 7 days (MV and DIV). Microhardness tests were carried out using a microdurometer in groups M and wear tests by a rugosimeter in groups D. The data were assessed by the one criterion variance analysis and Tukey test. Results: The mean value of microhardness, in KHN, in groups MI, MII, MIII, MIV and MV were 359,80; 335,46; 369,20; 377,73 and 341,86, respectively, whereas the mean values in $\mu \mathrm{m}$, of wear for group DI, DII, DIII and DIV were 0,$564 ; 0,519 ; 0,441$ and 0,428 , respectively. Conclusions: The sodium bicarbonate jet caused a wear and a reduction in microhardness on the enamel surface; saliva promoted the recovery of initial condition surface microhardness and reduced the wear; the repairing effect of saliva on the surface microhardness alterations occurred within one hour of treatment, having no significant statistical difference from the effect obtained in 24 hours; the best saliva repairing effect on the wear occurred with treatment of 24 hours.

Uniterms: Airpolishing; Tooth abrasion; Microhardness; Tooth remineralization.
\end{abstract}

\section{RESUMO}

bjetivo: A finalidade do trabalho foi avaliar as alterações da microdureza e o desgaste provocado pelo jato de bicarbonato de sódio em esmalte bovino e o posterior efeito remineralizador da saliva artificial. Métodos: Utilizaram-se 15 espécimes de esmalte (4,0 mm x 4,0mm) que constituíram os grupos: sem tratamento (MI); tratamento com jato de bicarbonato de sódio (MII e DI); tratamento com jato de bicarbonato de sódio e imersão em saliva artificial por uma hora (MIII e DII), 24 horas (MIV e DIII) e sete dias (MV e DIV). Foram realizados testes de microdureza com um microdurômetro nos grupos M e testes de desgaste com um rugosímetro nos grupos D. Resultados: Os dados foram avaliados pela Análise de Variância a um critério e pelo Teste de Tukey. O valor das médias da microdureza, em KHN, nos grupos MI, MII, MIII, MIV e MV foram 359,80; 335,46; 369,20; 377,73 e 341,86; respectivamente, enquanto que os valores médios, em $\mu \mathrm{m}$, do desgaste para o grupo DI, DII, DIII e DIV foram 0,564; 0,519; 0,441 e 0,428, respectivamente. Conclusões: o jato de bicarbonato de sódio causou desgaste e diminuição da microdureza superficial; a saliva promoveu o retorno da microdureza superficial à condição inicial e reduziu o desgaste; o efeito reparador da saliva sobre as alterações na microdureza superficial já ocorreu com uma hora de tratamento, não havendo diferença estatisticamente significante do efeito obtido com 24 horas; o melhor efeito reparador da saliva sobre o desgaste ocorreu com 24 horas de tratamento.

Unitermos: Jato de bicarbonato de sódio; Abrasão dentária; Microdureza; Remineralização dentária. 


\section{INTRODUCTION}

On the development of dental caries, bacterial plaque, plays an essential role, and thus, both the chemical and mechanical plaque control methods have been enphasized in modern dentistry.

One of the available professional and prophylactic methods consists in employing a sodium bicarbonate jet, which acts promoting a mechanical remotion of plaque and also a polishing from the dental surfaces (professional prophylaxis).

When a professional prophylaxis is carried out, a wear of the dental surface occurs. Several studies ${ }^{4,12,13,16,19}$ have quantified the ocurrence of sound enamel wear, but there is no consence as to the results, although it is known that the wear is higher when the prophylaxis is performed on the previously demineralized enamel ${ }^{3,5,8}$. Besides, there is a lack of information about the consequences related to this procedure on the superficial microhardness of enamel.

However, it is known that when there is a mineral loss on a tooth, a remineralization by the action of saliva occurs $1,10,17$. Saliva contains in its composition the main components of dental structure, as calcium and phosphate having a protective action on enamel and dentine ${ }^{11}$.

Although it is undoubtfull the benefit for caries prevention resulting from the plaque control, it is known that: the mechanical plaque remotion causes a certain wear of the enamel surface which quantification is not completely clarified yet; there is a lack of information on what happens to the enamel microhardness submitted to the prophylaxis; the enamel alterations originated from prophylaxis can be minimized by the remineralizator power of saliva, but it is still questionable how much of repair occurs and in which time span it occurs.

The present study intended to contribute to a better understanding of those aspects having as a purpose: to evaluate in vitro whether the application of the sodium bicarbonate jet on bovine enamel promotes wear and reduction of its surface microhardness and which is the effect of artificial saliva, in different periods of action, on the repairing of the possible occurred alterations.

\section{MATERIALAND METHODS}

After the remotion of the roots from 30 incisors bovine, the crowns were imbedded in thermoactivated godiva in a cristal acrilic plate, which has been coupled to a precision cutting device (ISOMET Low Speed Saw). With the aid of two duble faced diamond discs - XLI 2205, "high concentration", and a stainless steel spreader ( $7 \mathrm{~cm}$ diameter, $4 \mathrm{~mm}$ wide, and central orifice $1.3 \mathrm{~cm}$ ) between the discs, 30 enamel specimens with $4 \mathrm{~mm}$ X $4 \mathrm{~mm}$ taken from the plane portion of the crown, making a double secction in cervicoincisal direction and other in the mesiodistal direction.

Then, the enamel blocks were fixed with sticking wax in the center of a cristal acrilic disc (30 $\mathrm{mm}$ X 8mm), with the purpose of firstly perform the dentine planification. The set disc/tooth was adapted in a metalographic polishing device ( APL4, Arotec, Cotia, SP). For the planification a carbide silicon sandpaper granulation 320 (Extec Corp.) was used.

Following, the blocks were inverted and now fixed with the enamel placed on the upside face. The set was adapted to the polishing device and the enamel was polish with a carbide silicone sandpaper (Extec corp.) granulation 600, and further with a granulation 1200 sandpaper. In order to finish the polishing, a wet felt with a diamond suspention of $1 \mu \mathrm{m}$ (Buehler), was used.

The initial enamel surface microhardness was assessed using a microhardness measuring machine (HMV-2000/ Shimadzu Corporation, Japan) coupled to a microcomputer and a software specific for analysing images (Cams-WinNew Age Industries/USA). A Knoop indenter was used, with static load of 25g, applied for 5 seconds. In each sample five impressions were carried out. The blocks which microhardness was $10 \%$ over or under the average of all blocks, and those whose standard deviation was $10 \%$ above the value of its own mean were discarted. From the 30 specimens, 15 were selected. The research was carried out with the same 15 bovine enamel specimens wich were submited to surface microhardness and enamel wear tests.

For the study related to the surface microhardness (M) and enamel wear (D) five groups of specimens were constituted, according to the stage of treatment they were, such as: MI group - no treatment; MII and DI groups treatment with sodium bicarbonate jet; groups MIII and DII - treatment with sodium bicarbonate jet and immersion in artificial saliva for one hour; MIV and DIII groups - treatment with sodium bicarbonate jet and immersion in artificial saliva for 24 hours; MV and DIV groups - treatment with sodium bicarbonate jet and immersion in artificial saliva for seven days. For the treatment with sodium bicarbonate jet, half of the surface of each specimen was protected with red nail polishing. On the other half was applied the sodium bicarbonate jet (Dabi Atlante Industrias Médico Odontológicas LTDA) with a distance of $5 \mathrm{~mm}$ from the bovine enamel, during 10 seconds, with a $90^{\circ}$ angulation, without interruption. After this procedure, the nail polishing film was removed and, in this right moment, the specimens constituted the groups MII and DI. The enamel surface was evaluated with a rugosimeter Hommel Tester T 1000 (Hommelwerke, Gmbh, Alte Tuttinger Strebe 20 D-7730 VS Schwenningen) which was connected to a microcomputer. With the aid of a equipment software (Turbo Datawin-NT Version 1.34, Copwright (C 2001), besides the rugosity data, were also obtained the tested surfaces profiles. The measurement was carried out in five different sites of each block and the mean was obtained. Artificial saliva was manipulated by "Pharmácia Specífica Ltda, Bauru, Sao Paulo. Twenty ml of saliva were utilized which were individually stored in covered plastic vials, in incubator at $37^{\circ} \mathrm{C}$, for different periods of time, constituting the groups MIII and DII (1 hour), MIV and DIII (24 hours) and MV and DIV (7days). Saliva was dayly renewed. The obtained data were submmited to a statistical procedure by the variance analysis at one criterium and by the Tukey Test. 


\section{RESULTS}

The mean value (KHN) of superficial microhardness of bovine enamel, in the diferent experiment estages, can be seen in Table 1.

There was a statistically significant reduction in the enamel superficial microhardness following the treatment with sodium bicarbonate jet (MII), when compared to the initial superficial microhardness.

Data have shown that the permanency of the specimens in artificial saliva permited that the enamel surface microhardness, which was low after the prophylaxis (MII), has returned to the initial condition, because the values, both from Group MIII, and Group MIV as well as Group MV, did not present statistically significant differences related to the values of initial surface microhadness (MI).

Considering the immersion period of time of the specimens in saliva, there was no statistically significant difference in enamel superficial microhardness in Group MIII (1 hour), compared to Group MIV (24 hours). However, the superficial microhardness of Group MV was lower than those groups.

Table 2 contain the mean values $(\mu \mathrm{m})$ of the wear observed in bovine enamel, in the different phases of the experiment.

TABLE 1- Mean value of superficial microhardness (KHN) and standard deviation before and after prophylaxis and after immersion in artificial saliva in the different times of treatment

\begin{tabular}{llcl} 
Group & Mean & Standard deviation & Tukey test \\
\hline MI & 359.80 & 22.41 & ac \\
MII & 335.46 & 32.94 & $\mathrm{~b}$ \\
MIII & 369.20 & 26.01 & a \\
MN & 377.73 & 21.30 & a \\
MN & 341.86 & 26.04 & bc \\
\hline
\end{tabular}

Same letters denote no statistically significant difference $(p>0.05)$ by Tukey test

TABLE 2- Mean value of wear $(\mu \mathrm{m})$ and standard deviation after prophylaxis simulation and after immersion in artificial saliva in the different times of treatment

\begin{tabular}{llcl}
\hline Group & Mean & Standard deviation & Tukey test \\
\hline DI & 0.564 & 0.106 & $\mathrm{a}$ \\
DII & 0.519 & 0.103 & $\mathrm{ab}$ \\
DIII & 0.441 & 0.096 & $\mathrm{bc}$ \\
DIV & 0.428 & 0.084 & $\mathrm{c}$ \\
\hline
\end{tabular}

Same letters denote no statistically significant difference $(p>0.05)$ by Tukey test
The simulation of prophilaxis (DI) caused a enamel wear of $0.564 \mu \mathrm{m}$ which was repaired by the treatment with saliva. Within one hour immersion of the specimens in saliva (DII) the wear value had reduced to $0.519 \mu \mathrm{m}$, but the difference compared to the wear obtained following the prophylaxis simulation (DI) was not statistically significant.

The treatment with saliva for 24 hours (DIII) and by seven days (DIV) presented better results, because the wear values in these groups were lower than the value found in the specimens immediately after the prophilaxis simulation procedure (DI) at a level statistically significant.

\section{DISCUSSION}

This research was carried out with the same 15 bovine enamel specimens which were submitted to sucessive treatments. The employed methodology permitted this procedure. In the wear testing, the rugosimeter was used, which does not alter the tested surface allowing the further performance of other stages of the experiment. In the microhardness test, the KNOOP indenter was used, which neither produces distortions nor damages the enamel structure $^{15}$. These methods have made possible to evaluate sucessive alterations occurring in a same specimen.

The enamel surface profile was evaluated by a rugosimeter. As the bovine enamel was polished, the surface outline not treated by the sodium bicarbonate jet was similar to a straight line and thus, the alteration of this line observed on the enamel expressed the result of the prophylaxis simulation.

By the literature, it was possible to infer that, even though the enamel abrasion has not been considerable, it has been observed after prophylaxis procedures. Although there is report of wear on the enamel of deciduous tooth with the sodium bicarbonate jet ${ }^{9}$, it was not verified abrasion in sound enamel of permanent tooth with this procedure ${ }^{3,6,13,16}$. The wear caused by the sodium bicarbonate jet only occurred in human demineralized enamel ${ }^{3}$.

As the human enamel is less porous than the bovine enamel ${ }^{2,14,20}$, results of wear of both of them must not be compared without a careful understanding of this fact.

In bovine enamel, it was evaluated the wear caused by the sodium bicarbonate. Gerbo ${ }^{7}$ (1993) had observed no wear, whereas Honório ${ }^{8}$ (2003) and Fraga ${ }^{5}$ (2005), verified the presence of rugosity, which was higher on enamel previously demineralized than on the sound enamel.

In the present study, it was found a mean wear of $0.564 \mu \mathrm{m}$, following the simulation of prophylaxy with sodium bicarbonate jet. This value is higher than the one reported by Honório ${ }^{8}$ (2003), which was of $0.418 \mu \mathrm{m}$, and by Fraga ${ }^{5}$ (2005) which verified a wear of $0.319 \mu \mathrm{m}$.

It is known that small alterations on the enamel surface can reflect in its physical properties, one of them is the microhardness.

In this study the microhardness mean value of the initial bovine enamel surface, before any treatment, was 359.80 KHN, very close to the value reported by Newbrun; 
Timberlake; Pigman ${ }^{15}$ (1959), and higher than the value reported by Fraga ${ }^{5}$ (2005) which was of 300.47 KHN and lower compared to Honório ${ }^{8}$, wich was $394.0 \mathrm{KHN}$.

With the treatment of profylaxis simulation with sodium bicarbonate jet, the bovine enamel microhardness has reduced from $359.80 \mathrm{KHN}$ to $335.46 \mathrm{KHN}$, being the difference statistically significant. There was, therefore a loss of enamel hardness. In a research carried out by Fraga ${ }^{5}$ (2005) the application of the sodium bicarbonate jet has not altered the superficial microhardness of sound bovine enamel, but its mean value on the enamel presenting artificial carious lesion increased in a significant level, following the simulation of prophylaxis.

It is difficult to explain how, working in similar conditions, there was a discordance of results as to the sound enamel surface microhardness observed in the present study as well as in Fraga's study ${ }^{5}$.

The lack of previous studies in the literature, assessing the effect of sodium bicarbonate on the enamel related to the microhardness, impossibilitates a comparison of the values found in this research. This makes difficult to afirm if the result obtained here was the one expected or not.

Once that, in this in vitro study, alterations on the bovine dental enamel were found by the action of sodium bicarbonate jet, it is important to consider that if those alterations can occur in the clinical practice, although minimally, it can be expected the return to the initial conditions, simply by the fact that the tooth is constantly bathed by saliva.

In the present study, the specimens were treated by artificial saliva by periods of one hour, 24 hours, and 7 days. These periods of time were based on the study carried out by Fraga ${ }^{5}$ (2005) due to the lack of informations in the literature about the right moment when the effects of saliva can be detected in the repairing of the alterations resulting from the prophylaxis in sound enamel.

Fraga $^{5}$ (2005) could not detect any alterations in the microhardness value in sound teeth subjected to the prophylaxis simulation with sodium bicarbonate jet. Thus it is natural that the further treatment with saliva has not been reflected in this value.

Only with the immersion period in saliva for 28 days Fraga $^{5}$ (2005) obtained an alteration in wear and microhardness of enamel.

In the present research, in which there was a reduction in initial microhardness value following the treatment with the sodium bicarbonate jet, when the specimens were immersed in saliva, it could really be verified its effect in the restitution of the tissue integrity.

The specimens immersion in saliva, for just one hour, was enough for the microhardness to reach a value that was not different, statistically significant, from the initial value. The same has occurred with the immersion of the blocks in saliva for 24 hours and for 7 days, permiting to afirm that the repairing of the alterations generated by simulation prophylaxis already occurs, right after the contact with the saliva.

The treatment with saliva also had a repairing effect on the wear. With one hour of the specimens immersion in saliva, the wear value of $0.564 \mu \mathrm{m}$ caused by the prophylaxis simulation was reduced to $0.519 \mu \mathrm{m}$, although the difference has not been statistically significant.

However the treatment with saliva by 24 hours, had an expressive reduction of wear, which value was 0.441 with statistically significant difference from the value found after the application of the sodium bicarbonate jet.

There was no higher value in the result of wear with the extended period of immersion of the specimens in saliva for 7 days. It was similar to the one obtained with 24 hours of treatment.

Great discrepancy was found between these results and the Fraga's results ${ }^{5}$ which study the immersion period of 4 hours in saliva was not sufficient to alter the microhardness and the wear of hygid bovine enamel. Only with 28 days period of the specimens immersion in saliva, Fraga ${ }^{5}$ (2005) could observe an effect statistically significant of wear and microhardness in sound bovine enamel. However, the too long interval between the two observations (4 hours and 28 days) did not permit to know which was the period of time necessary to visualize an effect of treatment.

The results of the current research are in agreement to the Johansson ${ }^{10}$ (1965). The repairing effect of saliva, in the present work on the alterations on superficial microhardness and wear enamel was revealed in, at most, 24 hours, and, with the aditional time of 7 days no benefit was noted.

In the study of Johansson ${ }^{10}$ (1965) using demineralized human teeth, the remineralizing process by saliva occurred rapidly within the first 24 hours and there was no increment of mineral deposition with the immersion in saliva by a period of up to 3 weeks. A possible explanation for this fact is that, with the passing time, must occur an ionic difusion blocking toward the inner enamel, due to the mineral deposition in the most external layer.

This immediate remineralizing of enamel, when saliva or artificial remineralizing solutions with high calcium concentration are used, was verified in a literature review carried out by Silverstone ${ }^{19}$ (1977). Also, Ögaard; Ten Bosch $^{18}$ (1994) observed in vivo that the remineralization in the presence of saliva is a relatively rapid process.

Although it is not known, in which extension, the obtained results can be transfered to the clinical reality, the indication that the remineralizing process occurs very fast, simply by the action of saliva, this fact gives the dentist reassurement to perform the professional prophylaxis how many times it is necessary.

\section{CONCLUSIONS}

1. The application of sodium bicarbonate jet caused a wear and a reduction in the surface microhardness on bovine enamel.

2. The repairing effect of saliva on the surface microhardness alterations has occured as fast as one hour of treatment, presenting no statistically significant difference from the effect obtained with 24 hours. 
3. The wear resulting from the application of sodium bicarbonate jet were repaired in, at most, 24 hours, following the immersion in artificial saliva.

\section{REFERENCES}

1- Amaechi BT, Higham SM. In vitro remineralization of eroded lesions by saliva. J Dent. 2001;29(5):371-6.

2- Arends J, Schuthof J, Jongebloed WG. Lesion depth and microhardness indentations on artificial white spot lesions. Caries Res. 1980;14(4):190-5.

3- Boyde A. Airpolishing effects on enamel, dentine, cement and bone. Brit Dent J. 1984;156(8):287-91.

4- Christensen RP, Bangerter VW. Immediate and long-term in vivo effects of polishing on enamel and dentin. J Prosthet Dent. 1987;57(2):150-60.

5- Fraga ACA. Avaliação “in vitro” do efeito da profilaxia com jato de bicarbonato de sódio sobre o esmalte hígido e com lesão de cárie artificial e posterior remineralização. Bauru; 2005. [Dissertação de Mestrado - Faculdade de Odontologia de Bauru da USP].

6- Galloway SE, Pashley DH. Rate of removal of root structure by the use of the Prophy-Jet device. J Periodont. 1987;58(7):464-9.

7- Gerbo LR. Enamel roughness after air powder polishing. Am J Dent. 1993; 6(2):96-8.

8- Honório HM. Avaliação do desgaste de diferentes métodos de profilaxia sobre o esmalte bovino hígido e desmineralizado. Bauru; 2003. [Dissertação de Mestrado - Faculdade de Odontologia de Bauru da USP].

9- Hosoya Y, Johnsto NJW. Evaluation of various cleaning and polishing methods on primary enamel. J Pedod. 1989;13(3):253-69.

10- Johansson B. Remineralization of slightly etched enamel. J Dent Res. 1995;44(1):64-70

11- Lenz H. Ultrastructure of tooth in respect of mineralization, demineralization and remineralization. Int Dent J. 1967;17(4):693708

12- Lutz F, Imfeld T. Advances in abrasiveness: a new technology prophylaxis pastes. Comp Continuing Educ Dent. 2002;23(1):6170

13- Marta SN. Avaliação do efeito do jato de bicarbonato de sódio no esmalte de dentes permanentes jovens. Bauru; 1997. [Dissertação de Mestrado - Faculdade de Odontologia de Bauru da USP].

14- Mellberg JR. Hard-tissue substrates for evaluation of cariogenic and anti cariogenic activity in situ. J Dent Res. 1992;71(sp. Issue):9139 .

15- Newbrun E, Timberlake P, Pigman W. Changes microhardness of enamel following treatment with lactate buffer. J Dent Res. 1959;38(2):293-300.

16- Newman PS, Silverwood RA, Dolby AE. The effects of an air abrasive instrument on dental hard tissues, skin and oral mucosa. Brit Dent J. 1985;159(1):9-12.

17- Oesterle LJ, Shellhart WC, Belanger GK. The use of bovine enamel in bonding studies. Am J Orthod Dentofacial Orthop. 1998;114(5):514-9.
18- Ögaard B, Ten Bosch JJ. Regression of white spot enamel lesions. A new optical method for quantitative longitudinal evaluation in vivo. Am J Dent Orthop. 1994;106(3):238-42.

19- Silverstone LM. Remineralization phenomena. Caries Res. 1977b;11(Supplement 1):59- 84.

20- Wilson M. Bactericidal effect of laiser light and its potential use in the treatment of plaque-related diseases. Int Dent $\mathrm{J}$. 1994;44(2):181-9.

21- Zero DT. In situ caries models. Adv Dent Res. 1995;9(3):21430 